\title{
Accounting harmonization measurement: the case of non-banking financial institutions in Romania
}

\author{
Denis Levanti ${ }^{1, a}$, Ileana Cosmina Pitulice $^{\mathrm{a}}$ and Aurelia \\ Ştefănescu ${ }^{\mathrm{a}}$ \\ ${ }^{a}$ Bucharest University of Economic Studies, Romania
}

\begin{abstract}
Research Question: What is the degree of formal harmonization between IFRS and the national accounting framework currently applied by the non-banking financial institutions (NBFI) in Romania?
\end{abstract}

Motivation: Measuring the degree of formal accounting harmonization is beneficial in the context of the first-time adoption of IFRS by NBFI in Romania $(2019$ - 2022 for information purposes and starting with 2023 as basis for accounting). Despite the popularity of the accounting harmonization topic at the level of international literature, few studies envisage the particular cases of emerging countries, and especially of institutions operating in the financial services sector (banking and non-banking).

Idea: The objective of this paper is to evaluate the degree of harmonization between IFRS and the Romanian accounting framework currently applied by NBFI. Dissimilarities between the accounting policies under the two GAAPs are described and discussed.

Data: Sample for review consists of 38 accounting topics, selected from: IAS 1 "Presentation of financial statements", IFRS 1 "First time adoption of IFRS", IFRS 9 "Financial instruments", IFRS 16 "Leases" and IAS 12 "Income taxes".

Tools: Jaccard's similarity coefficient was used to measure the formal harmonization between IFRS and the Romanian accounting framework applicable to NBFI.

Findings: Based on the analyses conducted, a $38.89 \%$ similarity coefficient was determined. The areas where the accounting principles are the most compatible relate to the presentation of financial statements and the accounting by lessors. The most significant dissimilarities relate to the accounting principles for the classification, measurement and impairment of financial assets.

${ }^{1}$ Corresponding author: Department of Accounting and Audit, The Bucharest University of Economic Studies, Piața Romană, no 6, 1st district, Bucharest; email address: levantidenis10@stud.ase.ro 
Contribution: Enrichment of the literature in the field of formal accounting harmonization, as well as of the studies focused on institutions operating in the financial services sector, their number being currently limited. The results obtained provide valuable insights to both, representatives of the academic environment, as well as professionals within NBFI, with regards to the main differences between IFRS principles and the national accounting framework currently applied and specific adjustments to be performed when preparing the first set of IFRS financial statements.

Keywords: IFRS, convergence, harmonization, non-banking financial institution

\section{JEL codes: $\mathrm{M} 41$}

\section{Introduction}

This paper aims at measuring the degree of formal harmonization between the Romanian accounting framework applicable to non-banking financial institutions (NBFI) and IFRS. NBFI sourced financing has become increasingly popular in the European Union (EU) in recent years. These institutions have an important role in the economy as they supplement credit institutions in providing financial services to clients and, at the same time, create competition. While credit institutions may offer a set of financial services as a package deal, NBFI unbundle these services, tailoring them to particular groups. Additionally, individual NBFI may specialize in a particular sector, gaining an informational advantage. By this unbundling, targeting, and specializing tactics, NBFI promote competition within the financial services industry (The World Bank, 2020).

The evolution of the Romanian non-banking financial sector has led to new measures being enforced by the National Bank of Romania (NBR), which aimed to ensure the premises for better risk management as well as to diminish the regulatory arbitrage and to improve the potential systemic effects that may originate from this sector. One of these measures considers the harmonization of the financial reporting framework with IFRS. In this sense, on October 30, 2019, NBR issued Order no. 8/2019 (republished on 23 June 2020) ("NBR Order $8 / 2019$ "), which regulates the IFRS as basis for accounting for NBFI starting with January 1, 2023. To prepare for the implementation, NBFI are required to draw up for the financial years 2019-2022 a set of individual IFRS compliant financial statements, for information purposes.

This is an important milestone for the IFRS harmonization process in Romania. At European Union (EU) level, the IFRS application across the non-banking sector is not widely spread. According to the European Commission (EC) report on the IFRS applicability for different categories of companies (non-financial, credit 
institutions, insurance providers and other financial undertakings), there are only 11 Member States where the "other financial undertakings" are required to apply IFRS at individual level. In absence of any further descriptive information, it is presumed that NBFI are classified within this category. The limited IFRS application across NBFI is further confirmed by the results of the literature review.

To measure the degree of formal harmonization between the Romanian accounting framework and IFRS, we used Jaccard's similarity coefficient, a relevant instrument widely used in accounting studies (Fontes et al., 2005; Mustaţă, 2008; Strouhal et al., 2011). The analysis focused on a sample of 36 accounting principles covered by: IAS 1 "Presentation of financial statements" (IAS 1), IFRS 1 "First time adoption of IFRS" (IFRS 1), IFRS 9 "Financial instruments" (IFRS 9), IFRS 16 "Leases" (IFRS 16) and IAS 12 "Income taxes" (IAS 12).

Despite the popularity of the accounting harmonization topic at the level of international literature, few studies envisage the particular cases of emerging countries (Fontes et al., 2005; Mustață, 2008; Strouhal et al., 2011; Albu et al., 2011; Buculescu \& Velicescu, 2014). To the best of our knowledge, there are no empirical studies conducted on institutions operating in the banking and nonbanking sectors. The study is also relevant in the context of the limited IFRS applicability for NBFI at EU level.

The remainder of the paper is organized as follows: in Section 2, we reviewed the relevant international studies on formal harmonization measurement and presented the results obtained, while in Section 3 we discussed the institutional setting for the study. In section 4, we described the theoretical framework and the research methodology, while Section 5 is dedicated to the presentation and interpretation of results. In the final section, we summarize our conclusions and discuss the limitations of the study and future research directions.

\section{Literature review}

\subsection{IFRS adoption in the banking and non-banking sector}

Given the close links between banking and non-banking financial sectors, we conducted a review of the IFRS implementation stages for the banking sector, both at EU and local level. Thus, at EU level, the preparation of the IFRS financial statements by credit institutions has been introduced through Regulation (EC) no. 1606/2002 of the European Parliament and of the Council of 19 July 2002 on the application of international accounting standards, according to which all publicly traded companies, including credit institutions, operating in an EU Member State, were required to prepare their consolidated financial statements in accordance with IFRS starting with January 1, 2005. From then on, the national accounting frameworks applicable to the banking sector have been further updated, from one country to another. According to the EC report on the IFRS application across EU 
as of December 31, 2018, 12 out of the 28 Member States, including Romania, have required all credit institutions, irrespective of listed status, to prepare both their individual and consolidated annual financial statements in accordance with IFRS.

In Romania, the implementation of IFRS as basis for accounting of credit institutions took place in several stages and was declared one of the most difficult projects underwent by the Romanian banking system, with a significant impact on the banks' financials and operations (Grecu, 2011; Gîrbină et al., 2012). The implementation project was conducted by the key institutions operating in the accounting and banking regulatory framework, namely the Ministry of Finance (MF), NBR and the Romanian Banking Association (ARB).

In the context of the EU integration process, the national accounting framework applicable to credit institutions was updated in 2005 to align with the provisions of EU Regulation 1606/2002. As a first step of the transition process, starting with the financial year end 2006, all credit institutions operating in the Romanian banking system were required to prepare their consolidated annual financial statements in accordance with IFRS. Going forward, several assessments were conducted in order to evaluate the ability of the credit institutions to implement IFRS. This second stage of the process took three years, period during which credit institutions prepared an annual set of IFRS financial statements for information purposes. At the same time, the MF and NBR, defined the accounting regulatory framework in accordance with IFRS. The end of this preparation stage was marked by the issuance of the NBR Order no. 27 from December 2010, which regulated the IFRS as basis of accounting for credit institutions, starting with January 1, 2012. The financial year 2011 was considered a transitional year, during which these institutions carried out their internal implementation projects.

Compared to credit institutions, the convergence of the national accounting framework applicable to NBFI with the European Directives and IFRS evolved much slower. NBR fully transposed the provisions of the European Directives in the national accounting regulations by the end of 2011, these requirements being applicable starting with January 1, 2012. This moment coincides with the adoption of IFRS as basis of accounting for credit institutions. Only 7 years later, NBR prepared and submitted for public consultation a draft order by which it proposed the introduction of IFRS as basis for accounting for NBFI.

\subsection{Studies on the IFRS adoption in the banking and non-banking sector}

A documentary research was conducted in order to identify, review and interpret the results of the main studies performed on topics related to the accounting regulatory framework applicable to the non-banking financial institutions across 
the EU. The results of the research revealed that, while there are numerous studies conducted on the non-banking sector and the NBFI activity, few of them address the accounting regulatory framework matter. Moreover, in most of the cases, the studies targeted only a certain category of NBFI, especially leasing and microfinancing companies. For example, in case of leasing companies, HartmannWendels et al. (2014) developed a methodology to compute the loss given default indicator used for the computation of loan loss provisions, while Glaserova and Otavova (2010) studied the main differences between the lease accounting under IFRS and Czech GAAP. No studies on accounting related topics were identified in case of microfinancing companies.

As this paper aims to identify the differences between the accounting framework currently applied by NBFI and IFRS and to measure their harmonization level, and considering the similarities and links between the banking and non-banking financial sectors, we conducted a review of the main studies performed in respect of the IFRS transition for credit institutions in Romania. These studies represent an important and reliable source of information for conducting our research as the accounting framework applied currently by the Romanian NBFI is similar to the one applied by credit institutions before the IFRS adoption in 2012 .

Several studies explored the topic of the IFRS adoption by credit institutions in Romania. Researchers, academics, financial consultants and practitioners in Romania analyzed the impact of IFRS adoption on the banking system both prior and post IFRS implementation date. The majority of the ex-ante studies focused on identifying the key differences between the accounting policies applied under the national accounting framework and IFRS principles (Grecu, 2011; KPMG, 2011; Deac et al., 2012; Socol, 2012; Munteanu \& Brezeanu, 2012), as well as the benefits of IFRS implementation for the banking system (Ștefan \& Mușat, 2011; Gîrbină et al., 2012; Dochia, 2012). The outcomes of these studies are of a significant importance for the practitioners in the non-banking sector. Not only can they enrich their IFRS knowledge and understand the particular differences between the former accounting regulations for credit institutions (part of which are currently applied by NBFI) and IFRS principles, but also leverage on the implementation experience of the credit institutions, especially regarding the challenges encountered.

Grecu (2011) identified six main areas with a major impact on the financial statements or whose implementation required increased resources, namely: the impairment adjustment of financial assets, the recognition and measurement of financial instruments, the revenue recognition, deferred taxes, the consolidation of special purpose entities and financial statements disclosures. Same areas were also mentioned in the studies conducted by Deac et al. (2012), Socol (2012), Munteanu and Brezeanu (2012). Out of these main areas, the impairment adjustments for financial assets were considered to have the most significant 
impact on the financial results, as well as consuming the most resources allocated for the implementation project.

Deac et al. (2012) analyzed the main differences between the financial statements prepared in accordance with NBR regulations and those based on IFRS for a sample of four credit institutions operating in Romania. For the comparative analysis, the authors studied the statutory and IFRS financial statements for the financial years end 2009 and 2010, period during which the Romanian banking system was transitioning to IFRS. As compared to the results obtained by Grecu (2011), the authors identified an additional significant adjustment required for the IFRS transition, namely the value adjustments for hyperinflation, given that Romanian economy was hyperinflationary until December 31, 2003.

Similar to the studies carried out by Grecu (2011) and Deac et al. (2012), Socol (2012) analyzed the main differences between the provisions of the national accounting regulations and IFRS principles. Moreover, the author also analyzed the impact of IFRS implementation on the external audit process. The research includes a case study which analyzed the IFRS financial statements and the external auditor's report for the three credit institutions listed on the Bucharest Stock Exchange at the end 2011. In all cases, the auditors were concerned with determining the effects of the events occurring after the financial statements' reporting date, namely the IFRS implementation period starting with 2012. The studies conducted by KPMG during 2008 - 2011 focused on the evaluation of the impact that IFRS adoption had on equity and net result for a sample of 19 credit institutions. The results indicated that the value of the differences between the two GAAPS increased from one year to another, the most significant difference being related to the calculation of the impairment of loans.

\subsection{Studies on the measurement of accounting harmonization}

The literature on the measurement of accounting harmonization is growing and various methods to measure converge are developed and employed.

Canibano and Mora (2000) identified two different methodologies for measuring the level of harmonization: indices and statistical models. According to Mustata et al. (2011), the measurement of the degree of harmonization between two accounting standards can be conducted using three different types of indicators: 1) indicators which measure the concentration of options: by using Herfindahl Index $(\mathrm{H}$ index $)$ for national harmony, I Index for international harmony and Comparability Index (C Index), developed by Van der Tas (1998); 2) indicators based on measuring distance: Mahalanobis Distance Method, developed by Rahman et al. starting with 1996 and Euclidian Distances, used by Garrido et al. (2002) and Fontes et al. (2005); 3) indicators which measure the similitude degree: association coefficients (Jaccard's Coefficients) or correlation coefficients 
(Spearman Coefficient, Roger Tanimoto Coefficient and Lance Wiliams Coefficient). In terms of statistical models, the linear regression model developed by Archer et al. (1996) and the standard error model developed by Taplin (2003) are considered the most representatives.

As this paper aims at measuring the formal accounting harmonization, a review of the most representative international and national studies on this topic was conducted. Rahman et al. (1996) used multiple discriminant analyses to describe group differences as a way of measuring the harmonization degree between the accounting standards applied in Australia and New Zealand concerning disclosure and measurement requirements. The results indicated a higher harmonization degree on measurement requirements and a lower degree for disclosure requirements.

Garrido et al. (2002) demonstrated the application of Euclidean distances to the level of formal harmonization reached by the International Accounting Standards Board, through three different stages, by analyzing the pronouncements on 20 accounting issues. The results indicated that a reduction of the alternative accounting methods allowed by IASB had occurred, and consequently, the comparability of financial information had improved.

Fontes et al. (2005) explored three quantitative methods to measure the extent of convergence of any two sets of accounting standards, namely the Euclidean distances, Jaccard's coefficients and Spearman's correlation coefficient. For the purpose of the study, the authors analyzed a sample of 43 accounting issues in the Portuguese accounting standards and IFRS. The sample comprised accounting issues that have changed significant during the 1977-2003 period, in terms of their endorsement in both standards. All three methods explored indicated the convergence of the Portuguese GAAP with IFRS, however, the quality of the measures differs considerably. A 59\% convergence level was determined using Jaccard's similarity coefficient.

Ding et al. (2007) analyzed the determinants and the effects of the differences between the national accounting standards and IAS/IFRS. A list of such differences was used to create two indices, absence and divergence. Absence is defined as the extent to which the rules regarding certain accounting issues are missing from the national accounting standards but are covered by IAS/IFRS. Divergence represents the circumstances where the rules regarding the same accounting issue differ between the two standards. The sample included 30 countries for which the domestic standards applicable in 2001 were analyzed. The results indicated that absence is mainly determined by the importance of the equity market and ownership concentration, while divergence is positively associated with the level of economic development and the importance of the accounting profession, but is constrained by the importance of equity markets. Moreover, a higher level of 
absence implies more opportunities for earnings management, while a larger divergence from IAS/IFRS is associated with richer firm-specific information in capital markets.

Mustață (2008) estimated the evolution of the convergence of national standards with IFRS until 2007, using Jaccard's coefficient. The results of the study indicated that the level of convergence increased over time, reaching a $40.2 \%$ level for 2003 - 2007 period. To compute the convergence score, the author analyzed the accounting policies for 19 elements of the financial statements.

Strouhal et al. (2011) conducted a study to measure the harmonization level of the Czech, Estonian, Latvian and Romanian national accounting standards with IFRS for SMEs. For the comparability calculation, the authors used Jaccard's coefficients (to measure both similarities and dissimilarities), Roger-Tanimoto coefficient

(to measure similarities) and Lance-Williams coefficient (to measure dissimilarities). The aggregated results indicated that the most similar with the international referential are the accounting standards applied by Estonia and Latvia. The less compatible systems are those applied by Romania and Czech Republic. The similarity degree for Romania was determined at 53\%, with main differences observed in the tangible assets area.

Albu et al. (2011) conducted an analysis of the convergence level between the accounting policies applied for inventory items under the national accounting standards and IFRS for SMEs. The authors applied the methodologies of Ding et al. (2007) and Qu and Zhang (2020) to 20 inventory related items and computed a convergence and a divergence index. The results revealed a $51 \%$ convergence level.

Buculescu and Velicescu (2014) conducted a comparative analysis between IFRS for SMEs and the Romanian accounting regulations and measured the formal convergence level of the definitions, accounting treatment and policies applied for property, plant and equipment items. The authors used the methodology of Qu and Zhang (2010) and assigned scores for measuring the level of convergence between the items of both the standards, as follows: 1 for complete convergence, 0.7 for substantial convergence, 0.3 for substantial divergence and 0 for complete difference. The results revealed an overall medium convergence level (54.6\%), with higher value of convergence for definition and recognition policies and lower value for the scope and components requirements.

The above-mentioned studies focused on measuring the formal accounting harmonization between the national accounting standards, generally applicable to entities, and IFRS, including IFRS for SMEs. However, none of these studies envisaged the analysis of the national accounting standards specific to particular 
industries, such as the financial services industry. More specifically, the analysis of the convergence level between the national accounting standards applied by NBFI across the EU and IFRS is not yet approached in the accounting literature.

\section{Institutional setting and GAAP change}

Over the last few years, at EU level, the degree of financial intermediation conducted by the non-banking financial sector has increased. In case of Romania, according to the NBR's financial stability report as of June 2020, the degree of financial intermediation conducted at this sector level, as share in the Gross Domestic Product, is estimated at 17.6\% as of December 2019.

The non-banking financial sector in Romania is formed of private pension funds, investments funds, NBFI and insurance and reinsurance companies (listed upon their assets share in the total assets of the financial services sector, including credit institutions). According to NBR's annual report for 2019, as of December 2019, NBFI assets represented almost $6 \%$ of the total assets at the financial services sector level. The National Bank of Romania is the national authority responsible for NBFI regulation and supervision, while in case of the other entities from the non-banking financial sector, the regulatory and supervisory responsibilities rest with the Financial Supervisory Authority.

NBFI operating in the Romanian market prepare their statutory financial statements in accordance with NBR Order no. 6/2015 for the approval of the accounting framework according to the European Directives (NBR Order 6/2015). Additionally, the classification of loans granted to customers from a credit risk perspective and the computation of related impairment adjustments are performed based on the provisions of NBR Regulation 5/2012 on loans classification and computation of specific credit risk impairment adjustments, applicable to entities supervised by the National Bank of Romania, other than credit institutions (NBR Regulation 5/2012).

However, important changes were announced towards the end of 2019. On October 30, 2019, NBR issued Order 8/2019 which regulates IFRS as basis for accounting for all NBFI operating on the Romanian market, starting with January 1, 2022. In the context of COVID-19 pandemic, NBR issued a modified version of Order 8/2019 on June 23, 2020 and delayed the IFRS application date until January 1, 2023. For the financial years 2019 - 2022, NBFI are required to prepare, in addition to their statutory statements, a separate set of information IFRS financial statements. The information IFRS financial statements will be audited by the external auditor, except for those related to 2019 financial year. NBFI are required to submit to NBR the IFRS financial statements, together with the external auditor's report within a prescribed deadline. 


\section{Theoretical context and methodology}

To achieve the research objectives, we resorted to the use of institutional theory and quantitative research methods. The institutional theory has been widely used in conjunction with IFRS studies (Albu et al., 2014; Hassan et al., 2014; Aburous, 2019). The institutional theory provides a perspective that helps to understand how organizations respond to institutional pressures and expectations. It assumes that organizational practices, including financial reporting, are closely related to the values of the society where the entity operates, with a tendency to achieve homogeneity for maintaining organizational legitimacy (Deegan \& Unerman, 2011). The process of homogenizing organizational practices is called isomorphism and is defined as a constraint process that forces a unit in a population to resemble other units that face the same environmental conditions (DiMaggio \& Powell, 1983). There are three mechanisms that can be used for isomorphic change of organizations, namely: coercive isomorphism, through formal and informal pressures on organizations from third parties on which they depend on, mimetic isomorphism, through pressures to imitate organizations in conditions of ambiguity and uncertainty and normative isomorphism, through pressures to act professionally and to follow generally acceptable practices (DiMaggio \& Powell, 1983).

The accounting GAAP change of NBFI in Romania is based on both coercive isomorphism and normative isomorphism. We can argue that the need for GAAP change is based on coercive isomorphism as it is driven by formal pressures from the National Bank of Romania due to the evolution of the financial intermediation in the non-banking financial sector and of the subsequent implications deriving therein.

From a normative isomorphism perspective, IFRS are a set of accounting principles, recognized and applied at international level. These standards were created to establish a common language so that financial statements can be easily interpreted from company to company and country to country. As presented above, the development of the Romanian non-banking sector in recent years triggered the need for the GAAP change. Another important trigger in this sense was that all the other actors of the Romanian financial sector are currently applying IFRS as basis for accounting (entities whose securities are listed on regulated markets, credit institutions, investment funds, asset managers, alternative pension funds, central depositories, market/system operators and central counterparties) or preparing IFRS for information purposes (insurance and reinsurance companies). Thus, we can argue that the GAAP change is based also on normative isomorphism, as the NBFI were incentivized to follow the generally accepted accounting practices already applied by the other components of the Romanian financial sector. 
To measure the formal harmonization level between IFRS and the Romanian accounting framework applicable to NBFI, we used Jaccard's similarity coefficient, mostly known in the form applied by Fontes et al. (2005). Jaccard's similarity coefficient is defined as:

$\mathrm{S}_{\mathrm{ij}}=\mathrm{a} /(\mathrm{a}+\mathrm{b}+\mathrm{c})$, where

$\mathrm{S}_{\mathrm{ij}}$ represents the similarity between two sets of accounting standards or policies (denotes the relationship between the number of characteristics simultaneously present and absent in both set of standards and the total value of characteristics), ranging from 0 to 1 ;

a is the number of characteristics taking a value of 1 in both sets;

$\mathrm{b}$ is the number of characteristics taking a value of 1 in the $j$ th set and 0 in the $i$ th set;

$\mathrm{c}$ is the number of characteristics taking a value of 1 in the $i$ th set and 0 in the $j$ th set.

The accounting issues are coded as 1 for using a particular accounting method and as 0 for not using a particular accounting method.

The choice for using Jaccard's coefficient to conduct the study, in the detriment of other available methods for measuring formal accounting harmonization is motivated by: 1) it is recognized in the accounting literature as a relevant instrument to measure formal harmonization between two sets of accounting standards, and therefore it is widely used in accounting studies (Fontes et al., 2005; Mustață, 2008; Strouhal et al., 2011);2) it avoids contributing characteristics that are simultaneously absent in the computation of similarity between two sets of binary observations (Kranowski, 2000, cited in Fontes et al., 2005); 3) as compared to Euclidean distances, which can only be assessed in dynamic terms, Jaccard's coefficient can be interpreted also in static terms (Fontes et al., 2005).

The analysis focused on the accounting principles covered by: IAS 1 "Presentation of financial statements" (IAS 1), IFRS 1 "First time adoption of IFRS" (IFRS 1), IFRS 9 "Financial instruments" (IFRS 9), IFRS 16 "Leases" (IFRS 16) and IAS 12 "Income taxes" (IAS 12). IAS 1 and IFRS 1 principles were selected as they are relevant in the context of the first-time adoption of IFRS by NBFI and the preparation of the first full set of IFRS financial statements. IFRS 9 and IFRS 16 include the most representative accounting principles for NBFI given the specific of their activities, microfinancing and lease transactions. IAS 12 principles are relevant in the context of GAAP change as there will be differences between the accounting and fiscal bases of the different assets and liabilities elements.

The first step of the analysis consisted in the identification of the accounting principles from each selected IFRS to be matched with the requirements from NBR Order 6/2015. A sample of 36 accounting topics was selected for review. The next step involved the comparative analysis between the provisions of the two standards and the assignment of a convergence score. The third step marked the computation of Jaccard's similarity coefficient both at the level of individual accounting policies, as well as the overall convergence score. 


\begin{tabular}{|c|c|}
\hline IFRS & Accounting policies on: \\
\hline \multirow{12}{*}{$\begin{array}{l}\text { IAS } 1 \text { Presentation of } \\
\text { financial statements }\end{array}$} & Components of a complete set of financial statements \\
\hline & Fair presentation \\
\hline & Going concern \\
\hline & Accrual basis for accounting \\
\hline & Materiality and aggregation \\
\hline & Comparative information \\
\hline & Consistency of presentation \\
\hline & Structure and content of the statement of financial position \\
\hline & $\begin{array}{l}\text { Structure and content of the statement of profit or loss and } \\
\text { other comprehensive income }\end{array}$ \\
\hline & Structure and content of changes in equity \\
\hline & Structure and content of cash flows \\
\hline & Structure and content of the notes to the financial statements \\
\hline \multirow{4}{*}{$\begin{array}{l}\text { IFRS } 1 \text { First-time } \\
\text { adoption of IFRS }\end{array}$} & Transition date \\
\hline & Initial recognition of measurement according to IFRS \\
\hline & Comparative information \\
\hline & $\begin{array}{l}\text { Reconciliations between previous GAAP and IFRS for equity } \\
\text { and total comprehensive income }\end{array}$ \\
\hline \multirow{6}{*}{$\begin{array}{l}\text { IFRS } 9 \text { Financial } \\
\text { instruments }\end{array}$} & Classification and measurement of financial assets \\
\hline & Classification and measurement of financial liabilities \\
\hline & $\begin{array}{l}\text { Subsequent measurement of financial instruments at } \\
\text { amortized cost }\end{array}$ \\
\hline & $\begin{array}{l}\text { Subsequent measurement of financial instruments at fair } \\
\text { value }\end{array}$ \\
\hline & Revenue recognition \\
\hline & $\begin{array}{l}\text { Recognition and measurement of impairment of financial } \\
\text { instruments }\end{array}$ \\
\hline \multicolumn{2}{|r|}{ Not } \\
\hline & Accounting by lessees: \\
\hline & Identification of a lease contract \\
\hline & Initial recognition and measurement of a lease liability \\
\hline & Initial recognition and measurement of a right of use assets \\
\hline & Initial recognition and measurement exemption \\
\hline & Subsequent measurement of a lease liability \\
\hline & Subsequent measurement of a right of use assets \\
\hline & Accounting for a modification of a lease contract \\
\hline & Accounting by lessors: \\
\hline & Classification of lease contracts \\
\hline & Recognition and initial measurement of finance leases \\
\hline & Subsequent measurement of finance leases \\
\hline & Accounting for a modification of a finance lease contract \\
\hline & Accounting for operating leases \\
\hline IAS 12 Income taxes & Recognition and measurement of deferred tax liabilities \\
\hline & Recognition and measurement of deferred tax assets \\
\hline
\end{tabular}




\section{Results and discussion}

Table no. 2 provides evidence on the formal harmonization degree between IFRS and local accounting GAAP applied by NBFI. Based on the analyses conducted, a $38.89 \%$ similarity coefficient was determined. The areas where the accounting principles are the most compatible relate to the presentation of financial statements and the accounting by lessors. Details on the similarities and differences between the accounting principles under the two analyzed GAAPs are presented further.

Table 2. Similarity coefficient between provisions of IFRS and Romanian GAAP

\begin{tabular}{lc}
\hline Accounting policies under: & $\begin{array}{c}\text { Similarity coefficient }\left(\mathbf{S}_{\mathbf{i j}}\right) \\
(\boldsymbol{\%})\end{array}$ \\
\hline IAS 1 Presentation of financial statements & $58.33 \%$ \\
IFRS 1 First-time adoption of IFRS & $0 \%$ \\
IAS 12 Income taxes & $0 \%$ \\
IFRS 9 Financial instruments, out of which on & $16.67 \%$ \\
an individual basis: & $25 \%$ \\
Classification and measurement of financial & \\
instruments & $0 \%$ \\
Impairment of financial assets & $0 \%$ \\
Revenue recognition & $41.67 \%$ \\
IFRS 16 Leases, out of which on an individual & \\
basis: & $0 \%$ \\
Accounting by lessees & $100 \%$ \\
Accounting by lessors & $\mathbf{3 8 . 8 9 \%}$ \\
\hline Overall similarity coefficient & \\
\hline
\end{tabular}

\section{i. IAS 1 "Presentation of financial statements" principles}

An overall convergence score of $58.33 \%$ was determined with regards to IAS 1 provisions, following the analysis of 12 accounting issues. IAS 1 provides guidance on the overall structure of financial statements, including minimum requirements for each primary statement (statement of financial position, statement of profit or loss and other comprehensive income, statement of changes in equity and statement of cash flows) and notes to the financial statements.

The components of a complete annual set of financial statements are relatively similar under both IAS 1 and local GAAP, but with two important exceptions: 1) under the Romanian GAAP, the statement indicating the financial performance of entities resumes only to the presentation of profit or loss elements, with no presentation of other comprehensive income components. Consequently, this statement is titled "Statement of profit or loss"; 2) where an entity applies an accounting policy retrospectively or makes a retrospective restatement of items in its financial statements, or where it reclassifies certain items, IFRS requires the presentation of the statement of financial position as at the beginning of the 
preceding period. Under the local GAAP, entities are only required to present details on these reclassifications or restatements in the explanatory notes.

Both GAAPs provide for the general accounting principles related to fair presentation, going concern, accrual basis for accounting, materiality, comparative information and consistency of presentation. However, the most notable and significant dissimilarities were identified with respect to the structure and presentation of the primary statements. As opposed to IAS 1, which provide only for minimum presentation requirements for each primary statement, the Romanian accounting framework provides for a specific format of each primary statement, at component line level. There are prescriptive rules for mapping the internal accounts on each line of each primary statement. Moreover, the presentation criteria under the two GAAPs are different. With regards the statement of financial position, under IAS 1, Management should determine which is the most appropriate form of presentation for its elements, considering criteria such as the nature and liquidity of the assets, the function of the assets and the nature, timing and amounts of liabilities. This is not the case under the Romanian GAAP, which specifically requires NBFI to present the assets according to their nature and liquidity and the liabilities according to their nature and timing. Same situation is encountered in case of the statement of profit or loss. Under IAS 1, entities should present an analysis of the expenses using a classification based on either the nature of expenses or their function within the entities, whichever provides information that is reliable and more relevant. The local GAAP specifically requires the expenses to be presented based on their nature, according to a predefined format. The statement of changes in equity, the statement of cash flows and the explanatory notes are also prepared based on prescribed formats. Out of these, the cash flows presentation is closest to IFRS requirements.

\section{ii. IFRS 1 "First-time adoption of IFRS" principles}

IFRS 1 deals with the specific accounting principles applicable when an entity applies IFRS for the first-time. The local GAAP applies to all NBFI operating in the Romanian market, with no specific requirements for the first-time preparation of financial statements under the principles included therein. Thus, NBFI will have to apply IFRS 1 requirements in full. Therefore, the similarity degree between the two GAAPs in this respect was considered at $0 \%$.

The underlying principle of IFRS 1 is the retrospective application of the standards in force at the end of an entity's first IFRS reporting period. Entities must use the standards in force at the end of the latest period covered by their first IFRS financial statements in their opening IFRS balance sheet and throughout all periods presented in their first IFRS financial statements. Also, there are specific optional exemptions and some mandatory exceptions from this general requirement. A very important aspect is establishing the date of transition. According to the standard, the date of transition is the beginning of the earliest period for which an entity 
presents full comparative information under IFRS standards in its first IFRS financial statements. IFRS 1 requires an entity to prepare and present an opening balance sheet as a primary statement at the date of transition to IFRS. Thus, in the context of the first-time adoption of IFRS by Romanian NBFI, the following schedule apply:

Table 3. Timeline for the first-time preparation of IFRS financial statements

\begin{tabular}{|l|l|l|}
\hline January 1, 2019 & December 31, 2019 & December 31, 2020 \\
\hline $\begin{array}{l}\text { Opening statement of } \\
\text { financial position compliant } \\
\text { with IFRS }\end{array}$ & $\begin{array}{l}\text { Comparative financial } \\
\text { statements }\end{array}$ & $\begin{array}{l}\text { First full set of financial } \\
\text { statements compliant with } \\
\text { IFRS }\end{array}$ \\
\hline
\end{tabular}

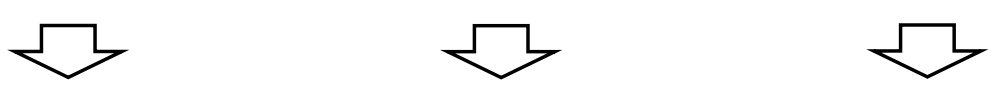

Only for entities applying the first-time information IFRS financial statements
Statement of financial position and financial performance

Source: authors' own analysis
Full set of IFRS financial statements subject of an external audit

\section{iii. IAS 12 "Income taxes" principles}

IAS 12 is the standard dealing with the accounting for income taxes. Its principles apply in situations where the accounting and fiscal of assets and liabilities are different, which are not currently regulated by the local GAAP. Thus, NBFI will have to apply in full IAS 12 principles both at transition date and at each reporting date. Therefore, the similarity degree between the two GAAPs in this respect was considered at $0 \%$.

The accounting for income taxes recognizes both the current tax consequences of transactions and events as well as the future tax consequences of the future recovery or settlement of the carrying amount of an entity's assets and liabilities. Any differences between (i) the carrying amount and tax base of assets and liabilities and (ii) carried forward tax losses and credits, are recognized as deferred tax liabilities or deferred tax assets, with the latter also being subject to a probable profits test. At transition date, NBFI will have to analyze the potential deferred tax impact deriving from the accounting policies changes that are made on transition to IFRS standards.

\section{iv. IFRS 9 "Financial instruments" principles}

The most notable discrepancies between the provisions of the local accounting framework and IFRS relate to the classification, measurement and impairment of financial instruments. A similarity coefficient of only $16.67 \%$ was determined between IFRS 9 and local GAAP provisions. This result is explained by the fact that 
IFRS 9 provisions, which are effective for annual reporting periods beginning on or after January 1, 2018, were not transposed into the local GAAP.

\section{Classification and measurement of financial instruments}

A $25 \%$ similarity coefficient was determined in respect of the accounting principles for the classification and measurement of financial instruments. The most significant differences were observed in relation to the principles applied for the classification and measurement of financial assets. The principles applicable to financial liabilities are relatively similar.

The accounting principles for the classification and measurement of financial suffered significant changes starting with January 1, 2018 when IFRS entered into force. Under this standard, all financial assets are initially measured at fair value and subsequently measured at either amortized cost, fair value through other comprehensive income (FVOCI) or fair value through profit or loss (FVPL). The conditions for such classification differ upon the financial asset type: debt or equity instrument. For debt instruments the business model and the solely payments of principal and interest (SPPI) assessments are considered for classification.

On the contrary, under the local GAAP, all financial instruments are initially recognized at acquisition cost, except for the derivative financial instruments, which are measured at fair value. The value of these assets is further assessed for impairment. Furthermore, the financial assets are classified within predefined investment categories, which are different than the categories included within IFRS. The classification criteria also are divergent. For example, a debt instrument is classified within the hold to collect category considering the intention and the ability of an entity to hold that instrument until maturity. This is not compliant with IFRS 9 principles, according to which the business model does not reflect an intention but refers to how an entity manages a financial asset in order to generate cash flows and is typically observed through activities that the entity undertakes to achieve the objectives of the business model. The SPPI test is not considered in the classification and measurement of financial assets.

\section{Impairment of financial assets}

The principles behind the assessment of impairment of financial assets are completely different. This assessment is a complex process, especially for specific categories of assets, such as the loans granted to customers. Currently, NBFI compute the loans' impairment according to the provisions of NBR Regulation $5 / 2012$. The methodology assumes the classification of the loans into five categories (standard, under observation, under-standard, doubtful, default), upon predefined criteria (days past due and status of debt recovery procedures). Each category is allocated an impairment coefficient based on which NBFI compute the impairment value. On the contrary, IFRS 9 outlines a three-stage model for 
impairment of financial assets, based on changes in credit quality since the initial recognition of the instrument. The significant increase in credit risk is assessed by comparing the risk of default at the reporting date with the risk of default at the date of initial recognition. Based on this assessment, Management determines the probability of an exposure to default and the loss given default. These statistical indicators are further used in the computation of impairment value.

\section{Revenue recognition}

According to IFRS 9 principles, the interest income and interest expenses deriving from financial instruments are recognized using the effective interest rate method. The effective interest rate is the rate that exactly discounts the estimated future cash flows or receipts throughout the financial instrument expected life to the gross carrying amount of a financial asset or to the amortized cost of a financial liability. The effective interest rate is adjusted to consider the origination fees received by entities for the development or acquisition of a financial asset, commitment fees to originate a loan (when the loan commitment is not measured at fair value through profit or loss), and origination fees paid on issuing financial liabilities measured at amortized cost.

The provisions of the local GAAP are partially consistent with the abovementioned provisions. Under the Romanian accounting framework, fees which are an integral part of the effective interest rate and transaction costs are recognized as an adjustment of the interest income, either by using a linear method or the effective interest rate. This is also applicable for interest expenses. Thus, considering the IFRS only allows for the recognition of revenue using the effective interest rate method, a $0 \%$ similarity coefficient was assigned for this accounting topic.

\section{v. IFRS 16 "Leases" principles}

Overall, a $41.67 \%$ similarity coefficient was determined in respect of lease accounting principles. An interesting situation is encountered for this topic as the accounting principles harmonization for the two leasing methods is at opposite poles: fully harmonized for lessor accounting and not harmonized at all for lessee accounting. The overall result was influenced by the number of accounting issues analyzed for ( 7 for lessee accounting and 5 for lessor accounting).

\section{Accounting by lessees}

The accounting principles for lease transactions suffered significant changes starting with January 1, 2019 when IFRS 16 entered into force. The changes envisaged the accounting from the lessee perspective. Under the new leasing model, the distinction between operating and finance lease is eliminated for lessees 
and a new lease asset and lease liability are recognized for all lease contracts, if no exemptions are applied.

These principles are not applicable under the local GAAP, whose provisions differentiate between finance and operating leases from the lessee perspective. Considering that these provisions are not aligned at all with IFRS, the similarity coefficient was established at $0 \%$.

\section{Accounting by lessors}

Lessor accounting did not change under IFRS 16 and lessors continue to reflect the underlying asset, subject to the lease arrangement, on the balance sheet for leases classified as operating. The principles for the classification of lease contracts into either finance or operating and the recognition and measurement principles are fully consistent with provisions of the local GAAP.

In conclusion, there are significant dissimilarities between the provisions of the two GAAPs in relation to the accounting issues selected for analysis. We envisage that NBFI will encounter numerous challenges during the IFRS conversion process. The degree of difficulty of IFRS conversion will depend on NBFI activity, the type, complexity and volume of activity. An important effect of IFRS convergence will be the increased effort at NBFI level to analyze and report all the information required to be presented in the financial statements. The simplest example can be observed for NBFI providing both consumer loans and finance lease products, where multiple accounting principles from different IFRSs will apply. The most significant challenges for the IFRS implementation are deemed to be the IT developments and staff training. Significant IT developments will be required especially for the implementation of IFRS 9 requirements in terms of impairment and revenue recognition based on the effective interest rate method. Furthermore, having highly trained employees will be of an ultimate importance for the quality of financial reporting and successful finalization of the implementation project. All these challenges will imply substantial costs.

NBFI should also consider the impact of the current economic environment in the context of COVID-19 pandemic on their IFRS implementation project. Special attention should be paid to the allocated budget and managing costs throughout the project given the uncertainties surrounding future cash inflows.

\section{Conclusion}

In this paper, we measured the formal harmonization degree between IFRS and the Romanian accounting framework applicable to NBFI, using Jaccard's similarity coefficient. The analysis focused on 36 accounting principles covered by IAS 1, IFRS 1, IFRS 9, IFRS 16 and IAS 12, which we considered relevant in the context of the first-time adoption of IFRS by NBFI in Romania and the specifics of the financial services sector. 
We obtained a $38.89 \%$ similarity coefficient, which indicates there are significant dissimilarities between the provisions of the two GAAPs. Out of these, the most significant relate to the accounting principles for the classification, measurement and impairment of financial instruments. The national accounting framework was not updated according to IFRS 9 principles. A similar situation is encountered also for lease accounting, where the Romanian GAAP still distinguishes between finance and operating lease contracts from a lessee perspective. We could not benchmark the results obtained against other studies as we did not identify in the accounting literature any studies focused on the measurement of formal harmonization for banking and non-banking financial institutions.

Given the low level of harmonization, we envisage that NBFI will encounter numerous challenges during the IFRS adoption process and will incur significant implementation costs, especially with IT developments and staff training. Special attention should be paid to the allocated budget and managing costs throughout the project given the uncertainties surrounding future cash inflows in the context of COVID-19 pandemic.

Our study contributes to the enrichment of the literature in the field of formal accounting harmonization, as well as of the studies focused on institutions operating in the financial services sector. The results obtained provide valuable insights to both, representatives of the academic environment, as well as professionals within NBFI, with regards to the main dissimilarities between IFRS and local GAAP principles, which can be used in the preparation of the first complete set of IFRS financial statements. Moreover, the study can be used as a benchmarking instrument by NBFI in other emerging countries at the moment of IFRS implementation.

This study is subject to several limitations. Firstly, our sample purposely did not include all IFRS, the analyses focused on IFRS relevant in the context of the firsttime adoption of IFRS and IFRS relevant for the financial services sector. Also, disclosure requirements from each of the analyzed standards were not considered. Secondly, the findings of this study are specific to Romania and could not be benchmarked against other settings or countries in absence of relevant studies in the accounting literature. Future research directions envisage the measurement of formal harmonization between the IFRS principles and accounting practices implemented by NBFI.

\section{Acknowledgements}

We appreciate the constructive feedback and suggestions received on the previous draft of this study presented at the International Conference Accounting and Management Information Systems (AMIS 2020), Bucharest, Romania. Special thanks are addressed to the anonymous reviewers of this research for their insightful recommendations. 


\section{References}

Aburous, D. (2019) "IFRS and institutional work in the accounting domain", Critical Perspectives on Accounting, vol. 62: 1-15

Albu, C., Gîrbină, M., Cuzdriorean-Vladu, D. (2011) "How close are Romanian regulations and the IFRS for SMEs? An in-depth analysis for inventories", Global Review of Accounting and Finance, vol. 3, no. 2: 32-41

Albu, C., Albu, N., \& Alexander, D. (2014) "When global accounting standards meet the local context - Insights from an emerging economy", Critical Perspectives on Accounting, vol. 25: 489-510

Archer, S., Delvaille, P., \& McLeay, S. (1996) "A Statistical Model of International Accounting Harmonization", Abacus, vol. 32: 1-29

Buculescu, M., \& Velicescu, B. (2014) "An analysis of the convergence level of tangible assets (PPE) according to Romanian national accounting regulation and IFRS for SMEs", Accounting and Management Information Systems, vol. 13, no. 4: 774-799

Cañibano, L., \& Mora, A. (2000) "Evaluating the statistical significance of de facto accounting harmonization: A study of European global players", European Accounting Review, vol. 9: 349-369

Deac, V., Vlad, M., \& Cioban, A. (2012) "Study on the alignment of the accounting regulatory framework on the IFRS for credit institutions in Romania", Procedia Economics and Finance, vol. 3:560-566

Deegan, C., \& Unerman, J. (2011) "In Financial accounting theory", 2nd European edition, Maidenhead: McGraw-Hill

DiMaggio, P., \& Powell, W. (1983) "The iron cage revisited: Institutional isomorphism and collective rationality in organizational fields", American Sociological Review, vol. 48: 147-160

Ding, Y., Hope, O.K., Jeanjean, T., \& Stolowy, H. (2007) "Differences between domestic accounting standards and IAS: Measurement, determinants and implications", Journal of Accounting and Public Policy, vol. 26, no. 1: 138

Dochia, A. (2012) "Comments on perceptions of preparers from Romanian banks regarding IFRS application", Accounting and Management Information Systems, vol.11, no. 2: 209-212

Fontes, A., Lima Rodrigues, L., \& Craig, R. (2005) "Measuring Convergence of National Accounting Standards with International Financial Reporting Standards", Accounting Forum, vol. 29: 415-436

Garrido, P., Leon, A., \& Zorio, A. (2002) "Measurement of formal harmonization progress: The IASC experience", The International Journal of Accounting, vol. 37: 1-26

Grecu, T. (2011) "Aplicarea IFRS în băncile românești - provocări din perspectiva managementului și auditului", Revista Audit Financiar, vol. 9, no. 12: 4247 
Gîrbină, M., Minu, M., Bunea, Ș, \& Săcărin, M. (2012) "Perceptions of preparers from Romanian banks regarding IFRS application", Proceedings of the Accounting and Management Information Systems Conference, 2012;

Gláserová, J., \& Otavova, M (2010) "Comparison of financial leasing according to the Czech accounting legislation and IAS/IFRS including tax implications", Acta Universitatis Agriculturae et Silviculturae Mendelianae Brunensis, vol. 58, no. 3: 55-66

Hartmann-Wendels, T., Miller, P., \& Töws, E. (2014) "Loss given default for leasing: Parametric and nonparametric estimations", Journal of Banking \& Finance, vol. 40: 364-375

Hassan, E., Rankin, M., \& Lu, W. (2014) "The development of accounting regulation in Iraq and the IFRS adoption decision: An institutional perspective", The International Journal of Accounting, vol. 49: 371-390

Mustață, R. (2008) "Sisteme de măsurare a armonizării şi diversităţi contabile internationale - intre necesitate si spontaneitate", Cluj Napoca: Casa Cărții de Știință

Mustaţă, R., Bonaci, C., Matis, D., \& Strouhal, J. (2011) "Using econometric tools for accounting harmonization measurement", International Journal of Mathematical Models and Methods in Applied Sciences, vol. 5: 316-323

National Bank of Romania Order no. 8/2019 on the IFRS adoption by the nonbanking financial institutions, available on-line at https://bnr.ro/apage. aspx ?pid=404\&actId=331155;

National Bank of Romania Order no. 6/2015 for the approval of accounting regulations in accordance with European Directives, available on-line at https://bnr.ro/apage-Mobile.aspx ?pid=404\&actId=328135;

National Bank of Romania Regulation no. 5/2012 for loans classification and computation of specific credit risk adjustments, available on-line at https://www.bnr.ro/apage. aspx ?pid=404\&actId=325076

Qu, X., \& Zhang, G. (2010) Measuring the convergence of national accounting standards with international financial reporting standards: The application of fuzzy clustering analysis", The International Journal of Accounting, vol. 45, no. 3: $334-355$

Rahman, A., Perera, H., \& Tower, G. (1996) "Accounting harmonization between Australia and New Zealand: Towards a regulation union", International Journal of Accounting, vol. 29, no.3: 316-333

Strouhal, J., Bonaci, C., Mustata, R., Alver, L., Alver, J., \& Praulinš, A. (2011) "Accounting harmonization measurement: Case of emerging CEE countries", International Journal of Mathematical Models and Methods in Applied Sciences, vol. 5: 899-906

Ștefan, C. \& Mușat, M. (2011) "Considerații privind reglementările BNR în contextul implementării IFRS de către sistemul bancar din România", Revista Audit Financiar, vol. 9, no. 10: 28-35

Taplin, R. (2003) "Harmony, Statistical Inference with the Herfindahl H Index and C Index", Abacus, vol. 39: 82-94 